Article

\title{
Alternative Agri-Food Systems under a Market Agencements Approach: The Case of Multifunctional Farming Activity in a Peri-Urban Area
}

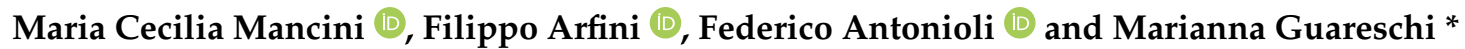 \\ Department of Economics and Management, University of Parma, 43125 Parma, Italy; \\ mariacecilia.mancini@unipr.it (M.C.M.); filippo.arfini@unipr.it (F.A.); federico.antonioli@unipr.it (F.A.) \\ * Correspondence: marianna.guareschi@unipr.it
}

check for

updates

Citation: Mancini, M.C.; Arfini, F.; Antonioli, F.; Guareschi, M. Alternative Agri-Food Systems under a Market Agencements Approach: The Case of Multifunctional Farming Activity in a Peri-Urban Area. Environments 2021, 8, 61. https:// doi.org/10.3390/environments8070061

Academic Editors: Gianluca Brunori and Sabrina Arcuri

Received: 1 April 2021

Accepted: 19 June 2021

Published: 24 June 2021

Publisher's Note: MDPI stays neutral with regard to jurisdictional claims in published maps and institutional affiliations.

Copyright: (c) 2021 by the authors. Licensee MDPI, Basel, Switzerland. This article is an open access article distributed under the terms and conditions of the Creative Commons Attribution (CC BY) license (https:// creativecommons.org/licenses/by/ $4.0 /)$.
Abstract: (1) Background: A large body of literature is available on the environmental, social, and economic sustainability of alternative food systems, but not much of it is devoted to the dynamics underlying their design and implementation, more specifically the processes that make an alternative food system successful or not in terms of its sustainability aims. This gap seems to be particularly critical in studies concerning alternative food systems in urban and peri-urban agriculture (UPA). This paper explores how the design and implementation of multifunctional farming activity in a peri-urban area surrounding the city of Reggio Emilia in the Emilia-Romagna region of Italy impact the achievement of its sustainability aims. (2) Methods: The environmental, social, and economic components of this project are explored in light of the sociology of market agencements. This method brings up the motivations of the human entities involved in the project, the role played by nonhuman entities, and the technical devices used for the fulfillment of the project's aims. (3) Results: The alternative food system under study lacked a robust design phase and a shared definition of the project aims among all the stakeholders involved. This ended in a substantial mismatch between project aims and consumer expectations. (4) Conclusions: When a comprehensive design stage is neglected, the threefold aim concerning sustainability might not be achievable. In particular, the design of alternative food systems must take into account the social environment where it is intended to be put in place, especially in UPA, where consumers often live in suburban neighborhoods wherein the sense of community is not strong, thus preventing them from getting involved in a communitybased project. In such cases, hybridization can play a role in the sustainability of alternative food networks, provided that some trade-offs occur among the different components of sustainabilitysome components of sustainability will be fully achieved, while others will not.

Keywords: alternative agri-food systems; market agencements; peri-urban areas

\section{Introduction}

The conventional agri-food production model has been increasingly perceived as unsustainable, to the extent that intensive agriculture and livestock farming have been pointed out as two of the human activities most responsible for environmental damage and involved in inequities, such as food waste and insecurity, animal suffering, and the unfair distribution of added value along the supply chain [1].

Beginning in the 1980s, the environmental crisis has gained increased attention from the world's policymakers, and sustainability has become one of the top-priority issues in their agendas. In 1987, The Brundtland Report defined sustainable development as "development that meets the needs of the present without compromising the ability of future generations to meet their own needs" [2]. In the 1980s, several models of alternative agri-food production aimed to move agriculture and consumption towards higher levels of sustainability worldwide. The range of such initiatives was referred to as "alternative food 
networks" (AFN). The literature defines these as forms of food provisioning with characteristics that differ from or seek to counter "conventional" modes of producing, distributing, and consuming food [3-5] and that include a variety of distribution and/or production practices, such as short supply chains, farmers' markets, community-supported agriculture, and farm shops, as well as consumer food co-operatives, specialist food retailers, organic agriculture, fair trade, and foods with a geographical indication of origin [6-8].

Whereas pioneering AFNs date back to the social movements of the 1960s committed to counteracting the globalization of industrial food systems and relocalizing food production and consumption [9], the mid-1980s is considered a crucial moment when AFNs moved away from being niche movements to gain the attention of a larger audience of consumers aware of the environmental and social impact of globalized agri-food chains. From then on, the concept of sustainable agri-food systems has been broadly discussed and refined; however, nowadays it is accepted that sustainable development requires a convergence between the three pillars of environmental protection, social equity, and economic development $[10,11]$. The intersection of the three dimensions of sustainability with AFN has given rise to a remarkable number of studies, focusing from time to time on specific issues such as AFNs' spatial features [7,12-14], the impact of AFNs on food quality [15-18], AFNs' contribution to rural development and cultural preservation [19-23], the role played by AFNs in environmental protection [24-27], and many others. Some authors have found a gap in the research when single axes of sustainability are analyzed [4,22,28,29], with a lack of comprehensive assessments, but recent contributions have partially filled this gap by providing methodological tools to measure the three dimensions of sustainability [30,31].

A recent field of research has approached the sustainability issue by focusing on the role of AFNs in urban and peri-urban areas. Urban and peri-urban agriculture (UPA) refers to activities located within or on the fringe of an urban area and related to the growth, processing, and distribution of agricultural and livestock products. Whereas it has been practiced in developing countries for a long time, UPA has only recently received increasing attention in developed countries [32]. In many U.S. and European cities, locally produced food has been acknowledged to be a response to increasing consumer concerns related to food safety and the environmental damage of conventional agri-food systems [33,34].

To the best of our knowledge, despite the large body of literature on AFN, not much research is available on the dynamics underlying AFN design and implementation, and more specifically on the processes that make an AFN work well or fail. This gap seems to be particularly critical in studies concerning UPA. As the narratives on AFN are mainly based on a retrospective view, many of the uncertainties, difficulties, and setbacks encountered in AFN design and implementation are lost because the focus is on final outcomes. In addition, the complexity of the process is often overlooked; as argued by Le Velly and Moraine [35] (p. 1000), "only little by little does the action stabilize around rules and identities that become 'black boxes' and are no longer challenged."

To contribute to fill this gap, this paper explores a case study based on the design and implementation of a multifunctional farming activity in a peri-urban area in Italy. This project is meant to be an in vivo experiment providing an environmentally and economically sustainable agri-food system, with the potential for scaling up in terms of the number of producers and consumers involved. To this end, the sociology of market agencements has been considered.

Section 2 explores the theoretical framework of the market agencements. Section 3 describes the aim and the method of analysis of the project. Section 4 is devoted to the project narrative, and the final two sections are composed of a discussion and final remarks.

\section{The Approach of the Market Agencements}

Anyone interested in studying markets must first decide on a definition of a "market". According to the economics discipline, the market is a mechanism through which buyers and sellers interact to determine prices and exchange goods and services. In such a setting, 
the actors who play a role in the market are individuals who act rationally or are subject to systematic biases in the definition of prices and the exchange of goods.

An important body of literature in the field of economic sociology, most prominently represented by Granovetter [36], contests the construction of the actor as an "atomistic individual" [37] and supports the idea of embedding the economic action in networks of interpersonal connections and cultural and political conditions. A complementary strand of research has been developed by Callon and Latour, who rooted their approach in the "actor-network theory" (ANT), a school of thought supporting the idea that agri-food markets need to be studied as associations of humans and nonhumans, social beings and natural beings [38], thus embracing the "hybridity" of any phenomenon under analysis. Callon and Latour confirmed the ANT vision of actors who are nonhuman entities, as well as human beings [39-41], and overcame any dichotomy still present in ANT-based studies [42] between, for instance, society and market, global and local, conventional and alternative. According to Latour, the analysis cannot analyze global forces on the one hand and local interactions on the other but has to consider the two processes as mutually determined [43]. The sociology of market agencements offers an opportunity to overcome the dichotomy while covering a series of studies on economic sociology inspired by ANT and acknowledging the role of the social sciences in revealing the more than rationally economic behavior in the performance of the markets.

The term "market agencements" merges the French word agencement, from the verb agencer (to arrange or to fit together), equivalent to the English "arrangement" or "configuration," and "agency," which entails the capacity to act. Agency is a collective phenomenon resulting from the associations that are established between human, material, and natural entities. Callon states that an actor is "made up of human bodies but also of prostheses, tools, equipment, technical devices, algorithms, etc.," whereas "action ... takes place in hybrid collectives ... that incorporate material and technical devices, texts, etc.," besides human beings [44] (p. 4). Thus, a market agencement is a sociotechnical arrangement or a hybrid setting resulting from the interaction of human and nonhuman entities able to take market action and organize the matching of supply and demand, appraise goods, set prices, and transfer ownership [2].

The relevance of such a definition is at least two-fold: on one side, the hybridity of the market acknowledges the inextricable intertwinement of conventional and alternative systems. The literature provides several examples showing how often interactions occur between the two paradigms [6,29]. For instance, on the demand side, consumers' expectations concerning food quality can overlap, regardless of the production and distribution system they refer to, whereas, on the supply side, AFN producers often prove to be influenced by conventional logics, such as selling at good prices [42]. Even the infrastructures the AFN rely upon are sometimes shared with conventional systems [45-47] — for instance, some segments of the distribution channels, like intermediate markets and warehouses.

The second issue worth underlining is the emphasis on the "material and technical devices" awarded by the sociology of market agencements. Some authors have explored the role and typologies of technical devices, ranging from the product packaging and supermarket shelves to quality standards and labels [48-51], which together enable economic transactions and shape consumer preferences. The choice of efficient devices to reach a given objective is up to the market professionals, namely retailers, wholesalers, and any other specialists that act in the market agencements [52].

Le Velly et al. [42] (p. 175), in line with ANT, argue that "the devices and professionals are not passive intermediaries between pre-existing supply and demand"; rather, they are mediators who take part in operations aimed at creating demand and supply. The authors recall some examples, such as consumer tasting [53], as a device able to influence the final demand, or tourist guides promoted by environmental associations that address both consumer choices and producer practices towards sustainability [54,55].

Although the notion of market agencements has gained attention within the fields of marketing and consumer research, the Callonian program offers an insightful approach to 
designing markets aimed at socially, morally, and politically acceptable ways of making exchanges. This view overcomes the traditional dualism between society (made up of networks, structures, and cultures) and the economy, in line with the market's rules, and calls for in-depth analysis of the social and cultural aspects that enable market exchanges.

We argue that the market agencements approach is particularly appropriate for studying AFN. Indeed, alternative models of food production are a response to consumers' expectations and producers' sensitivity in terms of food quality, social equity, and environmental protection. Thus, this approach allows us to study markets as a result of engagements by means of a narrative approach that describes the action in chronological order and untangles a variety of arrangements that would be barely understandable if considered from a retrospective view. It also shows that producers' characteristics and consumers' expectations are not a priori requirements but evolve as the processes evolve $[35,56,57]$.

The great emphasis of market agencements on nonhuman entities is of particular interest in AFN analysis as regards livestock or crops. Indeed, the characteristics of natural entities, namely seasonality, perishability, etc., impact their distribution and marketization. As a consequence, some devices, such as refrigerated transports, must receive particular care. Thus, the approach of market agencements aims at understanding the interactions between the human beings who produce the devices, the material devices that enable marketization, and natural entities that are the object of exchange in the market [35]. This paper will also benefit from a development of the market agencements approach, that is, the agencing of markets, proposed by Cochoy et al. [58], wherein the main emphasis is acknowledging that agents produce overflows [59], which, in turn, generate concerned groups [60] and open spaces for controversies in the market's governance. Thus, the agencing of markets can provide a new perspective on the ever-evolving interactions between actors and contribute to explaining how the dynamics that bring about the creation of new markets impact binaries like market/society, local/global, and conventional/alternative. Whereas these dynamics have been quite extensively explored in consumer studies, there is not much in the way of studies applying the sociology of market agencements to AFN design and implementation in UPA; our aim is to fill this gap.

\section{Aims and Methods}

The aim of this research is to analyze an AFN in a peri-urban area in the framework of the sociology of the market agencements. We explored the temporal sequence of the actions within the project, together with each involved entity's motivation, the effects of their interactions, and the devices that enabled the actions. As each action is the result of the arrangements of a collective made up of a number of entities, each one carrying a specific aim, there might be a mismatch between the designed aims and the actual outcomes. Therefore, the analysis explores the changing direction taken by the project as a consequence of the interactions between actors that produce overflows and open space for market instability. Such dynamics show how difficult is to ensure the successful synergy of all the human and nonhuman agents joining the experiment.

We analyzed the three-year "Parco Commestibile" (PC; Edible Park) project, aimed at promoting the socioeconomic role of a multifunctional farming activity in Canali, a peri-urban area of the town of Reggio Emilia, and potentially scaling it up in terms of the number of producers and consumers involved. To an extent, this project represents an example of an in vivo experiment-that is, a social engineering project aimed at achieving specific objectives [61]. The core idea of the project was to plant native trees and have a local farmer grow organic vegetables in an area made available by the municipality, then to market the fresh produce on the production site itself and offer mixed chopped fresh and frozen vegetables for soups at Conad and Coop outlets.

The project was designed and implemented by the Operational Group for Innovation in peri-urban agriculture and agroforestry (OGI) between October 2016 and December 2019. 
The OGI was made up of: (1) the CRPA (Centre for Research in Agricultural Production), the main designer of the project, which also dealt with the agroforestry planning, administrative coordination, and promotion of the project; (2) the "Cielo d'Irlanda" Cooperative, which agreed to grow organic vegetables and involve marginalized people in agricultural activities; (3) the "Ortolani" cooperative, the oldest cooperative in Reggio Emilia, which collects and sells local farmers' produce to retail outlets and has been involved in the production of mixed chopped fresh and frozen vegetable packs to be sold in Conad and Coop outlets; and (4) the University of Parma, namely the authors of this paper. We surveyed consumers' perceptions by creating two questionnaires, running a focus group, and interviewing OGI members (Table 1). Thus, as part of the group, we had the opportunity to watch the dynamics occurring whilst the project was being implemented.

Between October and November 2017, the first online questionnaire was e-mailed to all those citizens of Canali (100 people in total) who made their e-mail addresses available via public meetings and other dissemination activities organized by the OGI to promote the PC project.

The objective was to gather citizen feedback about the first year of the project and to align the following phases to their expectations as much as possible. Specifically, the questionnaire consisted of multiple-choice questions and was divided into the following sections: (1) the profile of the participants; (2) their purchasing preferences and consumption habits; (3) their degree of satisfaction with the project (food quality, prices, distribution channels, dissemination activities); and (4) their willingness to take an active part in the project, within activities such as dissemination.

The results of the first questionnaire were then shown to the participants of a focus group made up of 10 Canali citizens, chosen the same way as the questionnaire sample (that is, by inviting citizens whose e-mail addresses had been collected via public meetings and other dissemination activities organized by the OGI to promote the PC project). Weaknesses in the dissemination of the project, difficulties in involving citizens, and suggestions for adjusting the project were considered.

The University of Parma also conducted face-to-face interviews (in February-March 2018) with some OGI members (Table 1) to cover topics such as: (i) the reasons for the project (How was the project designed? What are the main needs underlying the project?); (ii) the different roles of the OGI members (How have you been involved in the project? What is your role within the project?); (iii) middle term-project strengths and weaknesses (What are the main project strengths and weaknesses? What has worked better/less well?); and (iv) problems that have emerged so far (What are the main problems? How were they fixed?).

Table 1. Interviewing OGI members.

\begin{tabular}{|c|c|c|c|c|}
\hline & Actor & Description & Date & Time \\
\hline 1 & \multirow{2}{*}{ CRPA } & \multirow{2}{*}{ Research Centre on Animal Production } & 26 February 2018 & $52 \mathrm{~m}$ \\
\hline 2 & & & 26 February 2018 & $65 \mathrm{~m}$ \\
\hline 3 & Soc. Coop. Ortolani & $\begin{array}{l}\text { Social cooperative that brings together } \\
\text { the farmers of the province and ensures } \\
\text { a sales channel through conventional } \\
\text { marketing circuits (Conad and Coop). }\end{array}$ & 28 February 2018 & $45 \mathrm{~m}$ \\
\hline 4 & Cielo d'Irlanda (farmer) & $\begin{array}{l}\text { Social production and direct sale } \\
\text { cooperative that employs socially } \\
\text { excluded people (prisoners) in } \\
\text { agricultural activities. }\end{array}$ & 2 March 2018 & $55 \mathrm{~m}$ \\
\hline
\end{tabular}

Source: authors' elaboration. 
Between October 2017 and October 2018, the Coop. Ortolani managed two tastings: in October 2017, 15 consumers tested mixes of seven frozen vegetables and seven fresh vegetables for soups. In October 2018, testing was carried out with 60 consumers between 20 and 81 years old with a mix of three frozen vegetables and a mix of three fresh vegetables, targeting those who had been most appreciative during the first experiment. The mixed chopped fresh and frozen vegetable packs were then sold at Conad and Coop stores.

Participants were contacted by e-mail and were drawn from those citizens who made their e-mail addresses available via public meetings and other dissemination activities.

In December 2019, a new online questionnaire was sent out to the same sample plus 30 more recent PC product consumers who were contacted outside the Conad store. The questionnaire's aim was to explore consumers' satisfaction with the most recent dynamics of the project (food quality, prices, distribution channels, other activities connected with the project). The questionnaire was divided into the following sections: (1) the profile of consumers; (2) their purchasing preferences and consumption habits; (3) the degree of satisfaction with the project (food quality, prices, method of sale, activities organized by the project); and (4) their perceptions of the political, economic, social, and technological aspects of the project.

No payment or other reward was received by the interviewees or those who took part in the testing.

STATA software version 16.0 was used to perform a statistical analysis of data.

Due to the small number of observations of both samples, the non-parametric Wilcoxon signed-rank test was used to verify whether the assessments of the respondents were statistically different (Data provided by the Municipality of Reggio Emilia (2015)).

However, the present study is deeply grounded in a sociological approach-that is, the sociology of market agencement. The data presented in Tables 2-11 are intended to support the authors' qualitative evaluations concerning the dynamics of an in vivo experiment in all its components. It is beyond the scope of this paper to identify statistically significant differences among the sociodemographic subgroups of the sample.

The Parco Commestibile has been interpreted as a market agencement, and we analyzed it in terms of all the human and nonhuman entities, as well as the technical and organizational devices.

\section{The Parco Commestibile Project}

\subsection{Designing and Implementing the In Vivo Experiment}

The Parco Commestibile project was funded by the Regional Rural Development Program 2014-2020.

As mentioned above, the core idea of the project was to plant trees and have a local farmer grow organic vegetables in an area made available by the municipality, then to market the fresh produce in the area itself on Saturday mornings and sell mixed chopped fresh and frozen vegetable packs at Conad and Coop outlets.

CRPA invited a farmer ("Cielo d'Irlanda") from Canali, selected by the Coop. Ortolani, to grow and sell certified organic vegetables.

In the meantime, CRPA presented the "Parco Commestibile" initiative at "Citizen Participation Workshops" open to Canali inhabitants, wherein the project received their approval.

The Coop. Ortolani was charged with the management of mixed chopped fresh and frozen vegetable pack production and distribution.

The first certified organic products were marketed at the beginning of 2017.

Initially, the products were sold on the production site every Saturday morning or via home deliveries. In the first months of 2017, however, supply exceeded demand.

To face up to the need for increased sales and the need for a meeting space, the OGI built a small wooden structure - the "little house"-placed on the production site in June 2017. The "little house" was supposed to be a temporary structure to be used until a community center was made available by the municipality. The community center was 
meant to be a central point in the dissemination strategy of the project but it has not yet been realized, thus causing a crucial gap in the relationship between the OGI and consumers.

\subsection{First Questionnaire and Focus Group Findings}

Nearly $43 \%$ of the interviewees of the first questionnaire were older than 60 , and $24 \%$ were in the 46-59 range. Thus, the sample composition was only partly representative of the Canali population, where $25 \%$ are older than 60 , and $24 \%$ are in the $45-59$ range (Data provided by the Municipality of Reggio Emilia (2015)). As far as the education level, nearly all the sample is represented by citizens holding a secondary and/or Bachelor's/Master's degree (97\%) (Table 2).

Table 2. Profiles of the questionnaire participants.

\begin{tabular}{|c|c|c|c|}
\hline & Categories & First Questionnaire & Second Questionnaire \\
\hline & & $\%$ & $\%$ \\
\hline Response rate & & 33 & 43.8 \\
\hline \multirow{2}{*}{ Sex } & Female & 51.5 & 58 \\
\hline & Male & 48.5 & 42 \\
\hline \multirow{4}{*}{ Age } & Over 60 & 42.4 & 43.8 \\
\hline & $46-59$ & 24.2 & 38.7 \\
\hline & $36-45$ & 27.3 & 14 \\
\hline & $26-35$ & 6.1 & 3.5 \\
\hline \multirow{4}{*}{ Degree } & Bachelor's/Master's degree & 54.6 & 40.4 \\
\hline & Secondary school degree & 42.4 & 40.4 \\
\hline & Professional degree & 3 & 3.5 \\
\hline & Primary school & 0 & 8.8 \\
\hline \multirow{3}{*}{ Profession } & Employed & 66.7 & 56.1 \\
\hline & Retired & 33.3 & 40.4 \\
\hline & Homemakers & 0 & 3.5 \\
\hline \multirow{3}{*}{ Household composition } & 2-3 people & 63.7 & 65 \\
\hline & 4 or more people & 27.3 & 28 \\
\hline & 1 person & 9.1 & 7 \\
\hline \multirow{3}{*}{$\begin{array}{l}\text { Number of meals eaten at } \\
\text { home per week }\end{array}$} & $10-14$ & 51.5 & 59.6 \\
\hline & $6-9$ & 48.5 & 31.6 \\
\hline & Fewer than 5 & 0 & 8.8 \\
\hline \multirow{3}{*}{ Meal preparation } & $\begin{array}{l}\text { Raw materials personally } \\
\text { processed }\end{array}$ & 87.9 & 89.5 \\
\hline & Use of semi-prepared food & 12.1 & 8.8 \\
\hline & Takeaway & 0 & 1.7 \\
\hline
\end{tabular}

Source: authors' elaboration.

The section about food purchasing habits showed that the most important factors influencing participants' choice when buying food products were seasonality and origin (Tables 3 and 4), followed by the environmental impact of farming activities, together with the knowledge of the farmer and supporting local farmers, whereas minor importance is given to organic certification and (not certified) natural products. With reference to the PC project, the participants' interest was focused on having access to local and high-quality products and supporting their local area (Table 5). 
Table 3. "When you choose a product, how important are the following characteristics?" $1=$ Not important; $5=$ Very important.

\begin{tabular}{|c|c|c|c|c|c|c|c|c|}
\hline & Not Important & & & & Impo & & & \\
\hline$\%$ & 1 & 2 & 3 & 4 & 5 & Mean & Median & No. of Answers \\
\hline Organic techniques & 12.1 & 33.3 & 18.2 & 27.3 & 9.1 & 2.9 & 3 & 33 \\
\hline $\begin{array}{c}\text { Natural products (not organically } \\
\text { certified) }\end{array}$ & 18.2 & 21.2 & 36.4 & 21.2 & 3.0 & 2.7 & 3 & 33 \\
\hline Seasonal products & 0.0 & 0.0 & 12.1 & 45.5 & 42.4 & 4.3 & 4 & 33 \\
\hline Locally produced products & 0.0 & 0.0 & 21.2 & 33.3 & 45.5 & 4.2 & 4 & 33 \\
\hline Food produced by small farmers & 0.0 & 18.2 & 24.2 & 30.3 & 27.3 & 3.7 & 4 & 33 \\
\hline Food produced by a known farmer & 9.1 & 3.0 & 24.2 & 24.2 & 39.4 & 3,8 & 4 & 33 \\
\hline $\begin{array}{l}\text { Low environmental impact of } \\
\text { production activities }\end{array}$ & 0.0 & 18.2 & 15.2 & 39.4 & 27.3 & 3,8 & 4 & 33 \\
\hline
\end{tabular}

Source: authors' elaboration.

Table 4. "When you choose a product, how important are the following characteristics?"—Wilcoxon signed-rank test: significance levels.

\begin{tabular}{|c|c|c|c|c|c|c|c|}
\hline $\begin{array}{c}\text { Wilcoxon } \\
\text { Signed Rank }\end{array}$ & $\begin{array}{c}\text { Organic } \\
\text { Techniques }\end{array}$ & $\begin{array}{c}\text { Not } \\
\text { Organically } \\
\text { Certified }\end{array}$ & $\begin{array}{l}\text { Seasonal } \\
\text { Products }\end{array}$ & $\begin{array}{l}\text { Locally } \\
\text { Produced }\end{array}$ & $\begin{array}{l}\text { By Small } \\
\text { Farmers }\end{array}$ & $\begin{array}{c}\text { By a Known } \\
\text { Farmer }\end{array}$ & $\begin{array}{l}\text { Low } \\
\text { Environmental }\end{array}$ \\
\hline $\begin{array}{c}\text { Organic } \\
\text { techniques }\end{array}$ & & - & $* * *$ & $* * *$ & $* * *$ & $* * *$ & $* * *$ \\
\hline $\begin{array}{c}\text { Not organically } \\
\text { certified }\end{array}$ & & & $* * *$ & $* * *$ & $* * *$ & $* * *$ & $* * *$ \\
\hline $\begin{array}{l}\text { Seasonal } \\
\text { products }\end{array}$ & & & & - & $* * *$ & $* *$ & $* * *$ \\
\hline $\begin{array}{l}\text { Locally } \\
\text { produced }\end{array}$ & & & & & $* * *$ & $* *$ & $* * *$ \\
\hline $\begin{array}{l}\text { By small } \\
\text { farmers }\end{array}$ & & & & & & - & - \\
\hline $\begin{array}{l}\text { By a known } \\
\text { farmer }\end{array}$ & & & & & & & - \\
\hline $\begin{array}{l}\text { Low } \\
\text { environmental }\end{array}$ & & & & & & & \\
\hline
\end{tabular}

*** $1 \%$ significance level, ** $5 \%$ significance level, "-" non-significant. Source: authors' elaboration.

Table 5. Why did you buy from or look for information on the PC project?

\begin{tabular}{ccc}
\hline & No. & \% \\
\hline To have access to healthy products & 16 & 32 \\
\hline To support my local area & 9 & 18 \\
\hline To get reconnected to nature & 6 & 12 \\
\hline Curiosity & 2 & 4 \\
\hline Personal ties with the farmer & 2 & 4 \\
\hline
\end{tabular}

Source: authors' elaboration.

It was also found out (Tables 6 and 7) that participants perceived the most crucial issue to be the availability of a large variety of seasonal vegetables, followed by the opportunity to buy all the vegetables they need in the same store, the proximity to home, and easy access by car. Less important were the "availability of organic food" and "a large variety of food in the same store", whereas the home-delivery service was perceived as the least importance service. 
Table 6. When you choose a point of sale, which of the following factors are important? $1=$ Not important; $5=$ Very important.

\begin{tabular}{|c|c|c|c|c|c|c|c|c|}
\hline & Not Important & & & & Impo & & & \\
\hline$\%$ & 1 & 2 & 3 & 4 & 5 & Mean & Median & No. of Answers \\
\hline Near home & 0.0 & 6.1 & 48.5 & 30.3 & 15.2 & 3.5 & 3 & 33 \\
\hline Home delivery service & 33.3 & 51.5 & 9.1 & 3.0 & 3.0 & 1.9 & 2 & 33 \\
\hline Reachable by car & 0.0 & 12.1 & 36.4 & 42.4 & 9.1 & 3.5 & 4 & 33 \\
\hline $\begin{array}{l}\text { I can find all the foods I need in } \\
\text { the same store }\end{array}$ & 3.0 & 36.4 & 30.3 & 27.3 & 3.0 & 2.9 & 3 & 33 \\
\hline $\begin{array}{l}\text { I can find all the vegetables I } \\
\text { need in the same store }\end{array}$ & 3.0 & 0.0 & 33.3 & 48.5 & 15.2 & 3.7 & 4 & 33 \\
\hline Availability of organic food & 9.1 & 30.3 & 33.3 & 18.2 & 9.1 & 2.9 & 3 & 33 \\
\hline $\begin{array}{l}\text { Availability of seasonal } \\
\text { products }\end{array}$ & 0.0 & 3.0 & 9.1 & 45.5 & 42.4 & 4.3 & 4 & 33 \\
\hline
\end{tabular}

Source: authors' elaboration.

Table 7. When you choose a point of sale, which of the following factors are important?-Wilcoxon signed-rank test: significance levels.

\begin{tabular}{|c|c|c|c|c|c|c|c|}
\hline $\begin{array}{c}\text { Wilcoxon } \\
\text { Signed Rank }\end{array}$ & Near Home & $\begin{array}{l}\text { Home } \\
\text { Delivery } \\
\text { Service }\end{array}$ & $\begin{array}{c}\text { Reachable by } \\
\text { Car }\end{array}$ & $\begin{array}{l}\text { All the foods I } \\
\text { Need in the } \\
\text { Same Store }\end{array}$ & $\begin{array}{l}\text { All the } \\
\text { Vegetables I } \\
\text { Need in the } \\
\text { Same Store }\end{array}$ & $\begin{array}{c}\text { Availability of } \\
\text { Organic Food }\end{array}$ & $\begin{array}{l}\text { Seasonal } \\
\text { Products }\end{array}$ \\
\hline Near home & & $* * *$ & - & $* * *$ & - & $* *$ & $* * *$ \\
\hline $\begin{array}{l}\text { Home delivery } \\
\text { service }\end{array}$ & & & $* * *$ & $* * *$ & $* * *$ & $* * *$ & $* * *$ \\
\hline $\begin{array}{l}\text { Reachable by } \\
\text { car }\end{array}$ & & & & $* * *$ & - & $* * *$ & $* * *$ \\
\hline $\begin{array}{l}\text { All the foods I } \\
\text { need in the } \\
\text { same store }\end{array}$ & & & & & $* * *$ & - & $* * *$ \\
\hline $\begin{array}{l}\text { All the } \\
\text { vegetables I } \\
\text { need in the } \\
\text { same store }\end{array}$ & & & & & & $* * *$ & $* * *$ \\
\hline $\begin{array}{c}\text { Availability of } \\
\text { organic food }\end{array}$ & & & & & & & $* * *$ \\
\hline $\begin{array}{l}\text { Seasonal } \\
\text { products }\end{array}$ & & & & & & & \\
\hline
\end{tabular}

*** $1 \%$ significance level, ** 5\% significance level, “-" non-significant. Source: authors' elaboration.

The first conclusion from the questionnaire findings show mismatches between some project activities and consumers' preferences, with particular reference to the marketing of the PC products. Indeed, consumers expressed their preference for convenient points of sale, wherein they can find a large variety of products, rather than on-field sales and home deliveries. The questionnaire also showed the need for larger involvement on the part of the main body of Canali citizens in the project.

The questionnaire findings were then brought to the attention of the focus group, and participants put forward some main issues. The first thing highlighted was the need to improve citizens' education about the cultural and ethical dimensions of the project. One participant said: "It is important to make the citizens aware of the concept of biodiversity" and another: "Kids have to be involved in the field ... they have to learn what seasonality means. Their involvement will make their parents more aware."

The price was also considered. One participant wondered: "Is it all about price? There are many initiatives competing on this. A farmer located in Correggio [a village located $20 \mathrm{~km}$ north of Reggio Emilia] is succeeding in selling his products because of 
very competitive prices." However, another said: "Talking about price is meaningless when referring to this initiative." Rather, the participants agreed on two main aspects: "Differentiation and communication. The concepts of biodiversity and organic techniques need to be disseminated as people are conscientious about this." And: "The consumers need to reach the product easily; it is also important to offer a larger variety of products, keeping the principle of seasonality, and online selling."

\subsection{Interviews with OGI Members}

Differences emerged between the farmer, who showed strict ethical and cultural motivations far from the conventional distribution system, and the Coop. Ortolani, which promoted sales via conventional retailing. The farmer claimed that the Coop. Ortolani's marketing strategies were inconsistent with the political and ethical message of the project: "what the Coop. Ortolani is doing today is meaningless [ ... ] [it] sells farmers' products to Coop and Conad to overcome its financial problems. This is the opposite of the principle the project rests upon."

The Coop. Ortolani representative did not agree with the crop scheduling defined by the farmer. The representative also emphasized the need for the farmer to be available in the field for sales every day, whereas he was only there on Saturday mornings.

Other aspects of the project found general agreement among the OGI members.

Both the farmer and CRPA were satisfied with the agronomic and agroforestry management of the field and the social dimension of the project, through which vulnerable people have been included in work activities (over the three years, 15 people were involved, including former prisoners, asylum seekers, and former drug addicts).

The OGI member agreed about the need to strengthen ties with citizens to make PC products more visible and promote community engagement to make the project selfsustainable in the long term. Indeed, CRPA stated: " ... . They [consumers] have to realize that there's no way to look for quality, seasonal food and, at the same time, find any kind of products, such as oranges."

Lack of communication about the production techniques and the values underlying the project were found to be major weaknesses for the project. In this regard, the farmer said: "A year and a half passed and our priority is to go on with the project. We have to tell the people that we are not a company. We produce in our territory, we do not use chemicals, etc. ... but we have to communicate what we do to build trust, otherwise no one will take care of the field at the end of the three-year project." CRPA expressed disappointment with the lack of citizen involvement: "There is not much participation ... there is this idea of participative democracy, but when it is time to participate, people prefer to stay home and watch television."

\subsection{The Project Adjustment and Second Questionnaire Findings}

Following the focus-group suggestions, the OGI launched some initiatives. The first one consisted of joining the REKO network, a Finnish trade model based on a pre-ordering system for local products through Facebook. The REKO initiative in Reggio Emilia is based on a group of 12 local farmers who sell their products to more than 2000 registered citizens. Once a week, farmers deliver the products to a predetermined place in Reggio Emilia. Joining this initiative allowed them to reach consumers outside of Canali. However, PC participation in REKO ended after a few months due to the lack of organization of the farmer, who did not have the time or managerial skills to stay in the network. The other two initiatives aimed at meeting consumers' needs by giving them a larger variety of products and the opportunity to buy PC products everyday while buying food other than vegetables. This entailed selling oranges produced by a Sicilian cooperative and, later on, making available unpacked PC products in a corner of the Conad outlet in Canali (until then, the Conad store had only sold packed PC products). These strategies were intended to involve new consumers and introduce the project to citizens who had not yet joined the initiative. In the period 2017-2019, farmers' annual revenues were estimated at around 
$€ 71,000-88,000$, while annual costs were $€ 67,000-82,000$. The result of ordinary operations, before taxes, was therefore $€ 4000-6000 /$ year.

To test the appreciation of the project after the adjustments, a second questionnaire was mailed.

The findings highlight that interviewees appreciate the values underlying the projects and the quality of the products, whereas the price is not a major issue compared to the other factors (Tables 8 and 9).

Table 8. "What is most important for you about this project?" $1=$ Not important; $5=$ Very important.

\begin{tabular}{|c|c|c|c|c|c|c|c|c|}
\hline & Not Important & & & & Impo & & & \\
\hline$\%$ & 1 & 2 & 3 & 4 & 5 & Mean & Median & No. of Answers \\
\hline Price & 1.8 & 12.3 & 35.1 & 31.6 & 19.3 & 3.5 & 4 & 57 \\
\hline Product quality & 1.8 & 8.8 & 19.3 & 35.1 & 35.1 & 3.9 & 4 & 57 \\
\hline Method of purchase & 3.5 & 14.0 & 17.5 & 35.1 & 29.8 & 3.7 & 4 & 57 \\
\hline $\begin{array}{c}\text { The values underlying } \\
\text { the project }\end{array}$ & 1.8 & 3.5 & 15.8 & 22.8 & 56.1 & 4.3 & 5 & 57 \\
\hline
\end{tabular}

Source: authors' elaboration.

Table 9. "What is most important for you about this project?"-Wilcoxon signed-rank test: significance levels.

\begin{tabular}{|c|c|c|c|c|}
\hline & Price & Quality & Method_Purchase & Values_Project \\
\hline price & & $* * *$ & $*$ & $* * *$ \\
\hline quality & & & $* *$ & $* * *$ \\
\hline method_purchase & & & & $* * *$ \\
\hline values_project & & & & \\
\hline
\end{tabular}

${ }^{* * *} 1 \%$ significance level, ${ }^{* *} 5 \%$ significance level, ${ }^{*} 10 \%$ significance level. Source: authors' elaboration.

Participants also showed to appreciate the availability of PC products at the Conad store. Indeed, $61 \%$ of the sample started to buy them once made available at the Conad store (Tables 10 and 11), but it was also pointed out the poor merchandising for the PC unpacked products at the Conad outlet as they were displayed in a corner outside the store, close to goods waiting to be stocked, thus lacking proper visibility.

Table 10. Impact of PC products' introduction in a Conad store-I.

\begin{tabular}{ccc}
\hline $\begin{array}{c}\text { Have You Started to Buy PC Products Since They Were Made } \\
\text { Available at the Conad Outlet? }\end{array}$ & No. of Answers & $\%$ \\
\hline No, I do not buy PC products & 5 & 8.8 \\
\hline No, I bought PC products before they were on sale at Conad & 17 & 29.8 \\
\hline Yes & 35 & 61.4 \\
\hline Total & 57 & 100 \\
\hline
\end{tabular}

Table 11. Impact of PC products' introduction in a Conad store-II.

\begin{tabular}{|c|c|c|c|c|c|c|c|c|}
\hline & I Do Not Agree & & & & $\begin{array}{l}\text { I Completely } \\
\text { Agree }\end{array}$ & Mean & Median & No. of Answers * \\
\hline & 1 & 2 & 3 & 4 & 5 & & & \\
\hline $\begin{array}{l}\text { I choose Conad because } \\
\text { of the PC products }\end{array}$ & 12.3 & 3.5 & 38.6 & 24.6 & 21.1 & 3.4 & 4 & 57 \\
\hline $\begin{array}{l}\text { When I go to the Conad } \\
\text { I look for PC products }\end{array}$ & 12.3 & 12.3 & 15.8 & 22.8 & 36.8 & 3.6 & 4 & 57 \\
\hline
\end{tabular}

\footnotetext{
* The Wilcoxon test was performed. No statistically significant differences were found. Source: authors' elaboration.
} 
The activities, actors, and devices involved in the project are summarized in Table 12.

Table 12. Entities, activities, devices, and market professionals in the PC market agencement.

\begin{tabular}{|c|c|c|c|c|c|c|}
\hline $\begin{array}{c}\text { Non Human } \\
\text { Entities }\end{array}$ & Human Entities & Time & Main Activities & Technical Devices & $\begin{array}{c}\text { Project } \\
\text { Adjustment }\end{array}$ & $\begin{array}{c}\text { Market } \\
\text { Professionals } \\
\end{array}$ \\
\hline \multirow[t]{2}{*}{$\begin{array}{l}\text { Trees, land, } \\
\text { vegetables }\end{array}$} & CRPA & $\begin{array}{c}\text { October 2016-De- } \\
\text { cember } 2019 \\
\end{array}$ & $\begin{array}{c}\text { Trees planting and } \\
\text { vegetables growing }\end{array}$ & & & \\
\hline & CRPA, citizens & $\begin{array}{c}\text { September 2017-Sep- } \\
\text { tember } 2019\end{array}$ & $\begin{array}{c}\text { Meeting Canali's } \\
\text { inhabitants }\end{array}$ & & & \\
\hline $\begin{array}{c}\text { Land, } \\
\text { vegetables } \\
\end{array}$ & Farmer & $\begin{array}{c}\text { January 2017-De- } \\
\text { cember } 2019 \\
\end{array}$ & Vegetable growing & Organic certification & & \\
\hline $\begin{array}{c}\text { Wooden } \\
\text { house }\end{array}$ & OGI & May 2017 & Little house opening & & & \\
\hline $\begin{array}{l}\text { PC unpacked } \\
\text { vegetables }\end{array}$ & Farmer & $\begin{array}{c}\text { May 2017-October } \\
2018 \\
\text { April 2018-October } \\
2019\end{array}$ & $\begin{array}{l}\text { On field and home } \\
\text { delivery }\end{array}$ & Boxes & & Direct sales \\
\hline $\begin{array}{l}\text { Chopped } \\
\text { vegetables } \\
\text { packs }\end{array}$ & Coop. Ortolani & $\begin{array}{c}\text { September-October } \\
2017 \\
\text { September-October } \\
2018 \\
\end{array}$ & Soup tasting & & & \\
\hline \multirow[t]{7}{*}{$\begin{array}{c}\text { Chopped } \\
\text { vegetables } \\
\text { packs } \\
\end{array}$} & Coop. Ortolani & $\begin{array}{c}\text { November 2018-De- } \\
\text { cember } 2019\end{array}$ & Soup selling & $\begin{array}{c}\text { Chopped PC labelled } \\
\text { vegetables packs }\end{array}$ & & $\begin{array}{c}\text { Coop and } \\
\text { Conad outlets }\end{array}$ \\
\hline & $\begin{array}{c}\text { CRPA, farmer, } \\
\text { citizens }\end{array}$ & $\begin{array}{c}\text { June 2017-December } \\
2019 \\
\end{array}$ & $\begin{array}{c}\text { Guided tours, } \\
\text { educational activities }\end{array}$ & & & Direct sales \\
\hline & $\begin{array}{c}\text { UNIPR, citizens, } \\
\text { consumers }\end{array}$ & $\begin{array}{c}\text { November-Decem- } \\
\text { ber } 2017 \\
\end{array}$ & Survey management & First questionnaire & & \\
\hline & $\begin{array}{l}\text { UNIPR, citizens, } \\
\text { consumers, OGI }\end{array}$ & $\begin{array}{c}\text { February-March } \\
2018\end{array}$ & $\begin{array}{c}\text { Focus group and } \\
\text { interviews }\end{array}$ & & & \\
\hline & & March 2018 & & & $\begin{array}{c}\text { Sicilian oranges } \\
\text { selling }\end{array}$ & Direct sales \\
\hline & & $\begin{array}{c}\text { March 2018-March } \\
2019\end{array}$ & & & $\begin{array}{l}\text { Joining REKO } \\
\text { initiative }\end{array}$ & $\begin{array}{c}\text { Direct sales } \\
\text { through } \\
\text { Facebook }\end{array}$ \\
\hline & & $\begin{array}{l}\text { April 2019-Decem- } \\
\text { ber } 2019\end{array}$ & & Poor merchandising & $\begin{array}{c}\text { Unpacked PC } \\
\text { vegetables sell- } \\
\text { ing at Conad } \\
\text { outlet }\end{array}$ & Large retailing \\
\hline & & $\begin{array}{c}\text { November-Decem- } \\
\text { ber } 2019\end{array}$ & Survey management & Second questionnaire & & \\
\hline
\end{tabular}

\section{Discussion}

The sociology of market agencements provided us with a theoretical framework to analyze the complexity of an in vivo experiment, from the engineering phase to its implementation - that is, the setting up of an AFN in a peri-urban area. Whereas traditional economic theory defines the market as a mechanism where the agents involved in the transaction are buyers and sellers, it is clear that here such borders would exclude some stakeholders whose behaviors are crucial for a deep understanding of the dynamics of the project.

Entities here are both human and nonhuman. The former entails several stakeholders who hold different and sometimes conflicting views on how to reach the project's aims.

Indeed, whereas the main objectives are set-that is, reconnecting producers and consumers through environmentally friendly products—and so are the main attachments, 
i.e., abandoned land in a peri-urban area and a farmer willing to grow organic vegetables, the other components of the collective seem to create asymmetries and even conflicts, thus making the market agencement unstable and partially unable to bring about the designed effects.

Evidence of how difficult it is to make an AFN successful is consumers' resistance to detach from some advantages belonging to conventional agri-food networks. Whereas Canali inhabitants said that they valued the principles underlying the PC project when it was still in the design phase, the same citizens wanted to go back to conventional distribution channels when put to the test. Indeed, although citizens seemed at first to appreciate being able to buy vegetables in the field by picking them themselves, they then realized that they preferred a conventional point of sale, open seven days a week, with convenient parking lots and a large variety of products not available in the field. This partly explains why conventional agri-food networks are difficult to replace and proves that efficient market professionals and devices are vital for alternative agri-food networks.

Later on, the project was adjusted by implementing some new initiatives, i.e., joining the REKO network, selling Sicilian oranges, and making unpacked PC vegetables available at the Conad outlet. Although this was meant to meet consumers' needs, in practice the adjustments brought about new dynamics that resulted in asymmetry and affected the market stability. Indeed, joining REKO resulted in failure due to the farmer's lack of organization and marketing skills, and sales in a retail outlet only partially succeeded. An effective market agencement would probably have required a market professional fully engaged in PC project logistics and communication to prevent the REKO initiative from being a failure and ensure the better visibility of PC products in the retailer outlet. Thus, the central role of marketing professionals in establishing stable market relations is confirmed.

Asymmetry and market instability are not necessarily counterproductive for AFNs, but they were in this project as, on the one hand, the farmer lost enthusiasm and could not maintain his involvement in the routine activities of the project and, on the other hand, unpacked PC product sales in the Conad outlet did not take off.

The nonhuman entities are firstly represented by PC products. Without them, both the OGI and the citizens miss the opportunity to build upon the project's aims. In other words, a market agencement cannot exist. However, some other devices proved to be crucial: indeed, the questionnaire has been the device used to gather the feedback that redirected the experiment towards different distribution channels and moved away from the organic certification scheme and home delivery boxes, whereas the lack of a physical place (i.e., the community center) undermined the relationship and the mutual understanding of actors motivations and needs.

According to Le Velly [35], a new AFN "needs to (i) agree on new definitions of quality, (ii) redefine the ways that goods and services are assessed, (iii) restore functional trading circuits, (iv) agree on prices, and (v) detach the actors from the customary networks" [35] (p. 1009).

In our case, these phases, with the exception of price setting, which does not seem to be a major aspect, were quite problematic and very much intertwined. Indeed, the definition of quality proved to be a critical issue, to the extent that a mismatch occurred in the quality perception as perceived by the OGI and consumers. When discussing this, it is worth pointing out that Canali is a so-called "dormitory area" where families spend very little of the lives. This has at least two important implications: the first is that only a few inhabitants had enough spare time to go shopping in the field and then to the store for products other than PC vegetables. This possibly explains why a large share of the citizens who joined the project were retirees who have enough time to go shopping in different outlets. The second, even more important implication, is that the lifestyle of Canali inhabitants, who are mainly daily commuters, prevented them from perceiving themselves as a community and from becoming involved in a community-based project. This helps us to understand why Canali citizens, even those who are retired, adopted a wider concept of quality, including attributes consistent with both AFN principles, such as seasonality, 
origin, and supporting a local farmer, and services of the conventional agri-food networks, i.e., parking lots, a large variety of products, etc. Some lessons to come out of this are: firstly, not to take the concept of quality for granted, even in an AFN context, as quality is always a hybrid concept, combining attributes of both the conventional and alternative food systems. Secondly, people show inconsistency to the extent that they support alternative projects in theory, but their behavior is driven by principles other than ethics when they act as consumers.

The mismatch in quality perception between the OGI and consumers about PC products also finds an explanation in the poor implementation of the following phase, "redefining the ways that goods and services are assessed." Indeed, CRPA admitted that the project lacked solid citizen education about fresh and seasonal food and, as a consequence, convenience was the actual driver of the project, rather than the ethical principles set by the OGI. Although some meetings took place aimed at presenting the project to the community, citizens were not involved in a proactive dialogue, at least not in the early stages of the project. This weakness is partly explained by the lack of a community center, which the municipality had promised to make available but never saw the light. This might open up a discussion as to whether it is advisable to rely upon an external actor, namely the municipality, which was marginally involved in the project and might have not perceived the pivotal role of the community center. Thus, the center is a nonhuman entity that could have made a difference to the project's outcome. Its replacement with an alternative place would be advisable to achieve reconnection between the producer and citizens/consumers, but this has not happened so far.

Similarly, the missing consensus on the "functional trading circuits" to put in place during the project design resulted in conflicting views between the farmer and the consumers concerning the proper points of sales for PC produce. Too late, the proactive role of consumers was acknowledged by organizing a focus group and adjusting the project according to consumer feedback.

Not only did poor citizen education and involvement fail to detach people from their customary networks, but it rather seems that the direction of the project activities moved the other way, from an alternative setting to a more conventional network, as a result of consumers' desires. This is a common worry on the part of the OGI members, who believe that the long-term sustainability of the project is undermined by the poor involvement of Canali citizens.

Detachment from routine networks was not a simple matter, either from the demand side or the supply side. Indeed, the supply side was shown not to have sufficient skills to join alternative distribution channels. This also implies that human entities (farmers and citizens) sensitive to ethical principles are not enough to render an AFN effective and stable. Indeed, farmers may not have received the organizational and marketing support to effectively join AFN, whereas citizens may not have received the proper education to make themself ready to act as AFN consumers.

In terms of the sociology of market agencements, consumers' attachment to AFN values is strictly related to their detachment from customary networks. This opens the field to the debate on AFN hybridization. Some authors have shown that AFNs very often rely upon conventional devices [62,63], as well as alternative devices, to assure the stability of the market agencements, even though hybridization has been criticized to the extent that it is inconsistent with AFN principles [64]. In the case under analysis, the request for intermediaries belonging to the conventional agri-food networks has highlighted some evidence: firstly, as mentioned above, it is hard for consumers, even those who appreciate the AFNs' principles, to give up some advantages of the conventional agri-food networks. Interestingly, the supply side also showed some weaknesses in managing sales through alternative channels. Indeed, direct sales and social-media-based distribution models (i.e., REKO) require technical and management skills that can be lacking on the part of the farmer. Secondly, a certain level of conventionalization can represent a useful tool to make the AFN work by increasing the visibility of and demand for PC products. However, 
conventionalization entails compromises, thus possibly weakening the strengths of AFN principles. In our case, the environmental aspects, i.e., tree planting and the recovery of the abandoned area, have been successfully implemented, whereas the social aim has been only partly fulfilled. Indeed, the involvement of marginalized people in the project worked well, whereas the reconnection of the producer with the consumers proved to be weak.

In general terms, it is hard to say to what extent conventionalization put the AFN's sustainability at risk. Here, it seems reasonable to foresee that one of the agents, the farmer, will detach from the agencement, having lost his enthusiasm, after the AFN conventionalization. This will cause an asymmetry that will end either with the failure of the experiment or other producers agreeing to join the agencement. Such dynamics could lead to a new agencement able to achieve economic sustainability, still very much unstable, and to scale up the experiment.

Some limitations to this research are acknowledged. Firstly, the samples of the questionnaires and tastings were very limited and not fully representative of the Canali citizenry. This may be considered as a flaw of the PC project rather than a limit of the paper. Indeed, the aim of this paper is to explore the temporal sequence of the actions within the project; therefore, we acknowledge this as one of the weaknesses of this project. Secondly, the questionnaires were sent to two convenience samples whose respondents were citizens contacted in public meetings and dissemination activities organized to promote the PC project and who were thus sensitive to the values underlying the project. Nevertheless, it is the authors' opinion that this is not a real limitation as the target of an AFN is not, by its nature, a standard consumer but a consumer sensitive to ethical principles who has, at the same time, the ability to cope with the constraints of everyday life. So, the point of the paper is how to make the AFNs more accessible to such a typology of consumer. In this regard, choosing convenience samples is justified.

Finally, we argue that the qualitative approach of the study makes the data provided by the questionnaires, the focus group, and the face-to-face interviews satisfactory for the purposes of the paper. Indeed, we used the data as supporting material for the analysis of the dynamics of an in-vivo experiment in all its components, together with the main points of conflict emerging from the interaction of them. Some qualitative considerations have come to light, which can be useful for future AFN implementations in PUA contexts and to address future research, with no intention to draw inferences and robust statistical-based conclusions.

\section{Conclusions}

The analysis of the case study from the market agencements lens showed that the PC project lacked a comprehensive design stage able to ensure the threefold aim concerning sustainability. Provided that the "alternative food network's alternativeness is a variable characteristic, rather a series of variable characteristics that the initiatives achieve to variable extents" [42] (p. 174), the case study indicates not only that a comprehensive design is necessary to set up an in vivo experiment able to meet specific aims, but also that the extent of the alternativeness has to be agreed upon in the design stage.

A lack of consensus on these issues leads to mismatches and conflicts.

The case under analysis showed that the lack of a common place where there can be a dialogue between the actors involved-the farmer, consumers, citizens, and other OGI members-and the late adjustments to gain proactive consumer involvement caused an asymmetry in the agencement, thus confirming the pivotal role of nonhuman entities, i.e., the community center, in the contribution to an effective AFN.

While it is true that alternative food movements use consumption as a tool to get citizens involved in the definition of alternative functioning of markets [65], the case under analysis shows that the dichotomy of alternative/conventional sometimes proves inadequate for an in-depth understanding of AFNs. Rather, it seems that hybridization can play a role in the sustainability of AFN, understanding that some trade-offs will occur among the different components of sustainability (to the extent that some objectives will be 
fully achieved, whereas others will not). In this case, hybridization offers a compromise, meeting the needs of those consumers who espouse ethical principles but, at the same time, are not willing to detach from some services provided by the conventional system. This study might also open up the field to more research on the characteristics of AFNs in peri-urban areas, where consumers often live in suburban neighborhoods without a strong sense of community, thus preventing them from getting involved in a community-based project. In such cases, hybridization can play a major role in setting up long-lasting AFNs.

Supplementary Materials: The following are available online at https:/ / www.mdpi.com/article/10 .3390/environments8070061/s1.

Author Contributions: Conceptualization, M.C.M. and M.G.; methodology, M.C.M., M.G., and F.A. (Filippo Arfini); software, F.A. (Federico Antonioli); formal analysis, M.G.; investigation, M.C.M. and M.G.; resources, M.C.M.; data curation, M.C.M. and M.G.; writing—original draft preparation, M.C.M. and M.G.; writing-review and editing, M.C.M. and M.G.; visualization, M.C.M.; supervision, M.C.M.; project administration, F.A. (Filippo Arfini) and M.G.; funding acquisition, F.A. (Filippo Arfini). All authors have read and agreed to the published version of the manuscript.

Funding: This research was funded by the Department of Agriculture, Hunting and Fisheries of the Emilia-Romagna Region. The initiative was carried out within the framework of the Regional Rural Development Programme 2014-2020 (Type of operation 16.1.01, Operational Group for European Innovation Partnership): "Agricultural productivity and sustainability"—Focus Area 2A.

Data Availability Statement: The data presented in this study are available in Supplementary Materials.

Acknowledgments: We would like to thank the CRPA for the cooperation during the project execution.

Conflicts of Interest: The authors declare no conflict of interest. The funders had no role in the design of the study; in the collection, analyses, or interpretation of data; in the writing of the manuscript, or in the decision to publish the results.

\section{References}

1. FAO (Food and Agriculture Organization of the United Nations). FAO Statistical Yearbook 2013-World Food and Agriculture; FAO: Rome, Italy, 2013.

2. Brundtland, G. Report of the World Commision on Environement and Development: Our Common Future; Oxford Pap.: Oxford, UK, 1987.

3. Murdoch, J.; Marsden, T.; Banks, J. Quality, nature, and embeddedness: Some theoretical considerations in the context of the food sector. Econ. Geogr. 2000, 76, 107-125. [CrossRef]

4. Tregear, A. Progressing knowledge in alternative and local food networks: Critical reflections and a research agenda. J. Rural Stud. 2011, 27, 419-430. [CrossRef]

5. Mancini, M.C.; Arfini, F.; Guareschi, M. Innovation and typicality in localised agri-food systems: The case of PDO Parmigiano Reggiano. Br. Food J. 2019, 121, 3043-3061. [CrossRef]

6. Arfini, F.; Cozzi, E.; Mancini, M.C.; Ferrer-Perez, H.; Gil, J.M. Are geographical indication products fostering public goods? Some evidence from Europe. Sustainability 2019, 11, 272. [CrossRef]

7. Renting, H.; Marsden, T.K.; Banks, J. Understanding alternative food networks: Exploring the role of short food supply chains in rural development. Environ. Plan. A 2003, 35, 393-411. [CrossRef]

8. Mancini, M.C.; Arfini, F. Short supply chains and protected designations of origin: The case of parmigiano reggiano (Italy). Ager Rev. De Estud. Sobre Despoblación Y Desarro. Rural J. Depopulation Rural Dev. Stud. 2018, 25, 43-64.

9. Brinkley, C. The smallworld of the alternative food network. Sustainability 2018, 10, 2921. [CrossRef]

10. Allen, P.; Van Dusen, D.; Lundy, J.; Gliessman, S. Integrating social, environmental, and economic issues in sustainable agriculture. Am. J. Altern. Agric. 1991, 6, 34-39. [CrossRef]

11. Maxey, L. Can we sustain sustainable agriculture? Learning from small-scale producer-suppliers in Canada and the UK. Geogr. J. 2006, 172, 230-244. [CrossRef]

12. Higgins, V.; Dibden, J.; Cocklin, C. Building alternative agri-food networks: Certification, embeddedness and agri-environmental governance. J. Rural Stud. 2008, 24, 15-27. [CrossRef]

13. Chiffoleau, Y. From politics to co-operation: The dynamics of embeddedness in alternative food supply chains. Sociol. Rural. 2009, 49, 218-235. [CrossRef]

14. Sforzi, F.; Mancini, M.C. The reinterpretation of the agri-food system and its spatial dynamics through the industrial district. Agric. Econ. Czech 2012, 58, 510-519. [CrossRef] 
15. Barjolle, D.; Boisseaux, S.; Dufour, M. Le Lien au Terroir. Bilan des Travaux de Recherche; Institut d'économie rurale: Lausanne, Switzerland, 1998; pp. 1-33.

16. Banks, J.; Bristow, G. Developing quality in agro-food supply chains: A welsh perspective. Int. Plan. Stud. 1999, 4, 317-331. [CrossRef]

17. Goodman, D. The quality 'turn' and alternative food practices: Reflections and agenda. J. Rural Stud. 2003, 1, 1-7. [CrossRef]

18. Mancini, M.C. La Denominazione di Origine Protetta: Uno strumento di tutela del consumatore? Il caso del Prosciutto di Parma. Prog. Nutr. 2012, 14, 161-176.

19. O'Hara, S.; Stagl, S.U. Global Food Markets and Their Local Alternatives: A Socio-Ecological Economic Perspective. Popul. Environ. 2001, 22, 533-554. [CrossRef]

20. Barham, E. Translating terroir: The global challenge of French AOC labeling. J. Rural Stud. 2003, 19, 127-138. [CrossRef]

21. Colin, S. Social embeddedness and relations of regard: alternative 'good food' networks in south-west Ireland. J. Rural Stud. 2003, $19,47-60$.

22. Goodman, D. Rural Europe Redux? Reflections on alternative agro-food networks and paradigm change. Sociol. Rural. 2004, 44, 3-16. [CrossRef]

23. Dupont, J.; Fiebelkorn, F. Attitudes and acceptance of young people toward the consumption of insects and cultured meat in Germany. Food Qual. Prefer. 2020, 85, 103983. [CrossRef]

24. Hedberg, R.C. The ecology of alternative food landscapes: A framework for assessing the ecology of alternative food networks and its implications for sustainability. Landsc. Res. 2016, 41, 795-807. [CrossRef]

25. Schoolman, E.D. Do direct market farms use fewer agricultural chemicals? Evidence from the US census of agriculture. Renew. Agric. Food Syst. 2019, 34, 415-429. [CrossRef]

26. Mariola, M.J. The local industrial complex? Questioning the link between local foods and energy use. Agric. Hum. Values 2008, 25, 193-196. [CrossRef]

27. Duram, L.; Oberholtzer, L. A geographic approach to place and natural resource use in local food systems. Renew. Agric. Food Syst. 2010, 25, 99-108. [CrossRef]

28. Winter, M. Embeddedness, the new food economy and defensive localism. J. Rural Stud. 2003, 19, 23-32. [CrossRef]

29. Watts, D.C.H.; Ilbery, B.; Maye, D. Making reconnections in agro-food geography: Alternative systems of food provision. Prog. Hum. Geogr. 2005, 29, 22-40. [CrossRef]

30. Forssell, S.; Lankoski, L. The sustainability promise of alternative food networks: An examination through 'alternative' characteristics. Agric. Hum. Values 2015, 32, 63-75. [CrossRef]

31. Malak-Rawlikowska, A.; Majewski, E.; Wąs, A.; Borgen, S.O.; Csillag, P.; Donati, M.; Freeman, R.; Hoàng, V.; Lecoeur, J.-L.; Mancini, M.C.; et al. Measuring the economic, environmental, and social sustainability of short food supply chains. Sustainability 2019, 11, 4004. [CrossRef]

32. Hall, G.; Rothwell, A.; Grant, T.; Isaacs, B.; Ford, L.; Dixon, J.; Kirk, M.; Friel, S. Potential environmental and population health impacts of local urban food systems under climate change: A life cycle analysis case study of lettuce and chicken. Agric. Food Secur. 2014, 3, 1-13. [CrossRef]

33. Benis, K.; Ferrão, P. Potential mitigation of the environmental impacts of food systems through urban and peri-urban agriculture (UPA)_A life cycle assessment approach. J. Clean. Prod. 2017, 140, 784-795. [CrossRef]

34. Jones, A. An environmental assessment of food supply chains: A case study on dessert apples. Environ. Manag. 2002, 30, 560-576. [CrossRef]

35. Le Velly, R.; Moraine, M. Agencing an innovative territorial trade scheme between crop and livestock farming: The contributions of the sociology of market agencements to alternative agri-food network analysis. Agric. Hum. Values 2020, 37, 1-14. [CrossRef]

36. Granovetter, M. Economic Action and Social Structure: The Problem of Embeddedness. Am. J. Sociol. 1985, 91, 481-510. [CrossRef]

37. Hardie, I.; Mackenzie, D. Assembling an economic actor: The agencement of a Hedge Fund. Sociol. Rev. 2007, 55, 57-80. [CrossRef]

38. Goodman, D. Agro-food studies in the 'Age of Ecology': Nature, corporeality, bio-politics. Sociol. Rural. 1999, 39, 17-38. [CrossRef]

39. Callon, M. Some elements of a sociology of translation: Domestication of the scallops and the fishermen of St Brieuc Bay. Sociol. Rev. 1984, 32 Suppl. 1, 196-233. [CrossRef]

40. Callon, M.; Latour, B. Unscrewing the big Leviathan: How actors macrostructure reality and how so. In Advances in Social Theory and Methodology: Toward an Integration of Micro-and Macro-Sociologies; Routledge: Abingdon-on-Thames, UK, 1981 ; Volume 1.

41. Callon, M. Some elements of a sociology of translation. Power, Action Belief. Sociol. Rev. Keele 1986, 32, 1-280.

42. Le Velly, R.; Dufeu, I. Alternative food networks as "market agencements": Exploring their multiple hybridities. J. Rural Stud. 2016, 43, 173-182. [CrossRef]

43. Latour, B.; Teli, M. Reassembling the Social: An Introduction to Actor-Network-Theory; Oxford University Press: Oxford, UK, 2005.

44. Callon, M. Why virtualism paves the way to political impotence. A reply to Daniel Miller's critique of The Laws of The Markets. Econ. Sociol. Eur. Electron. Newsl. 2005, 6, 3-20.

45. Clarke, N.; Cloke, P.; Barnett, C.; Malpass, A. The spaces and ethics of organic food. J. Rural Stud. 2008, 24, 219-230. [CrossRef]

46. Cleveland, D.A.; Müller, N.M.; Tranovich, A.C.; Mazaroli, D.N.; Hinson, K. Local food hubs for alternative food systems: A case study from Santa Barbara County, California. J. Rural Stud. 2014, 35, 26-36. [CrossRef] 
47. Lamine, C.; Renting, H.; Rossi, A.; Han Wiskerke, J.S.C.; Brunori, G. Agri-Food systems and territorial development: Innovations, new dynamics and changing governance mechanisms. In Farming Systems Research into the 21st Century: The New Dynamic; Springer: Dordrecht, The Netherlands, 2012; pp. 229-256.

48. Cochoy, F. Calculation, qualculation, calqulation: Shopping cart arithmetic, equipped cognition and the clustered consumer. Mark. Theory 2008, 8, 15-44. [CrossRef]

49. Ekström, K.M.; Brembeck, H.; Cochoy, F. Is the Modern Consumer a Buridan's Donkey? Product Packaging and Consumer Choice. In Elusive Consumption; Routledge: London, UK, 2004; pp. 205-227.

50. Callon, M.; Muniesa, F. Economic markets as calculative collective devices. In Organization Studies; SAGE Publications: Thousand Oaks, CA, USA, 2015; Volume 26.

51. Kjellberg, H.; Helgesson, C.F. The mode of exchange and shaping of markets: Distributor influence in the Swedish post-war food industry. Ind. Mark. Manag. 2007, 36, 861-878. [CrossRef]

52. Araujo, L.; Finch, J.; Kjellberg, H. Reconnecting marketing to markets: An introduction. In Reconnecting Marketing to Markets; Oxford University Press: Oxford, UK, 2010.

53. Callon, M.; Méadel, C.; Rabeharisoa, V. The economy of qualities. Econ. Soc. 2002, 31, 194-217. [CrossRef]

54. Dubuisson-Quellier, S.A. Market Mediation Strategy: How Social Movements Seek to Change Firms' Practices by Promoting New Principles of Product Valuation. Organ. Stud. 2013, 34, 683-703. [CrossRef]

55. Karpik, L. Le Guide rouge Michelin. Sociol. Du Trav. 2000, 42, 369-389. [CrossRef]

56. Lockie, S.; Kitto, S. Beyond the farm gate: Production-consumption networks and agri-food research. Sociol. Rural. 2000, 40, 3-19. [CrossRef]

57. Wang, C.M. Performing and counter-performing organic food markets in East Asia: The role of ahimsa, scientific knowledge and faith groups. Geogr. J. 2019, 1-12. [CrossRef]

58. Cochoy, F.; Trompette, P.; Araujo, L. From market agencements to market agencing: An introduction. Consum. Mark. Cult. 2016, 19, 1-14. [CrossRef]

59. Czarniawska, B.; Löfgren, O. Coping with Excess: How Organizations, Communities and Individuals Manage Overflows; Edward Elgar Publishing: Northampton, MA, USA, 2013.

60. Geiger, S.; Harrison, D.; Kjellberg, H.; Mallard, A. Concerned Markets: Economic Ordering for Multiple Values; Edward Elgar Publishing: Northampton, MA, USA, 2014.

61. Callon, M. Civilizing markets: Carbon trading between in vitro and in vivo experiments. Account. Organ. Soc. 2009, 34, 535-548. [CrossRef]

62. Bloom, J.D.; Hinrichs, C.C. Informal and Formal Mechanisms of Coordination in Hybrid Food Value Chains. Informal and Formal Mechanisms of Coordination in Hybrid Food Value Chains. J. Agric. Food Syst. Community Dev. 2011, 1, 143-156. [CrossRef]

63. Klein, K.; Michas, A. Print E-mail The Farm Fresh Healthcare Project: Analysis of a Hybrid Values-based Supply Chain. J. Agric. Food Syst. Community Dev. 2014, 5, 57-74. [CrossRef]

64. Nost, E. Scaling-up local foods: Commodity practice in community supported agriculture (CSA). J. Rural Stud. 2014, 34, 152-160. [CrossRef]

65. Dubuisson-Quellier, S.; Lamine, C.; Le Velly, R. Citizenship and consumption: Mobilisation in alternative food systems in France. Sociol. Rural. 2011, 51, 304-323. [CrossRef] 